Discussion Paper No. 11-027

Determinants of Eco-innovations by Type of Environmental Impact The Role of Regulatory Push/Pull, Technology Push and Market Pull

Jens Horbach, Christian Rammer, and Klaus Rennings

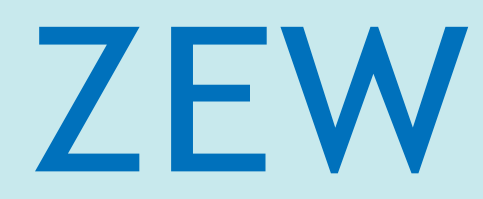

Zentrum für Europäische Wirtschaftsforschung $\mathrm{GmbH}$ Centre for European Economic Research 
Discussion Paper No. 11-027

\title{
Determinants of Eco-innovations by Type of Environmental Impact The Role of Regulatory Push/Pull, Technology Push and Market Pull
}

\author{
Jens Horbach, Christian Rammer,
} and Klaus Rennings

Download this ZEW Discussion Paper from our ftp server:

ftp://ftp.zew.de/pub/zew-docs/dp/dp11027.pdf

Die Discussion Papers dienen einer möglichst schnellen Verbreitung von neueren Forschungsarbeiten des ZEW. Die Beiträge liegen in alleiniger Verantwortung der Autoren und stellen nicht notwendigerweise die Meinung des ZEW dar.

Discussion Papers are intended to make results of ZEW research promptly available to other economists in order to encourage discussion and suggestions for revisions. The authors are solely responsible for the contents which do not necessarily represent the opinion of the ZEW. 


\section{Non technical summary}

In recent years, several studies have identified determinants of environmental innovations. In most econometric studies, environmental innovations in general were analyzed, some distinguish between end-of-pipe-innovations and cleaner production. Due to the lack of specific data, the existing literature on the driving forces of environmental innovations neglected the analysis of different environmental innovation types such as recycling, low carbon technologies or water management.

The Community Innovation Panel (CIS) 2009 included, for the first time, a special module on eco-innovation differentiating between these specific types of environmental innovations. Analysing the German part of the CIS 2009, the main purpose of our paper is to test whether different types of environmental innovations (according to their environmental impacts) are triggered by different factors.

Within our analysis, we define environmental innovations as product, process, marketing and organizational innovations leading to a noticeable reduction of environmental burdens. Positive environmental effects can be explicit goals or side-effects of innovations.

In the literature, the important role of regulation and cost savings as motivations triggering eco-innovations is accentuated. In fact, a complex set of supply factors such as the endowment and availability of technological resources, company specific factors, organizational innovations, competition conditions or consumer demand have to be included in the analysis. Our empirical analysis shows that the innovation activities with high or medium environmental impacts concentrate on the reduction of energy use, $\mathrm{CO}_{2}$ emissions and recycling whereas "older" areas such as the reduction of $\mathrm{SO}_{2}$ or $\mathrm{NO}_{\mathrm{x}}$ emissions or water pollution that are not in the focus of present political discussions are under-represented.

Except material and energy saving process innovations, regulations seem to be important for all other environmental impact areas. Especially for typically end-of-pipe oriented areas such as other air emissions $\left(\mathrm{SO}_{2}\right.$ or $\left.\mathrm{NO}_{\mathrm{x}}\right)$ the influence of present and future regulations is higher than for other areas. For innovations to reduce energy use cost-savings are the main motivation. Environmental Management Systems (EMS) seem to be especially important tools to trigger these cost-saving cleaner technologies because they help to overcome incomplete information within a firm. Concerning environmental product innovations, our results show that present regulations are only relevant for air, water, soil and noise emissions but not for the other two regarded areas (energy consumption and recycling) but the firms confirm a high importance of expected future regulations for all environmental product innovations. 


\section{Das Wichtigste in Kürze}

In den letzten Jahren hat die Forschung zur Analyse der Bestimmungsgründe von Innovationen im Umweltbereich an Bedeutung gewonnen. Die diesbezüglichen ökonometrischen Untersuchungen konzentrierten sich dabei auf Umweltinnovationen im Allgemeinen, lediglich einige unterschieden dabei etwa zwischen End-of-pipe und integrierten Umwelttechnologien. Aufgrund des Mangels an geeigneten Daten hat die bestehende Literatur die Analyse der Determinanten unterschiedlicher Umweltinnovationsbereiche wie Recycling, kohlendioxidarme Verbrennungstechniken oder Wasserreinigung vernachlässigt. Das Hauptziel dieses Artikels ist es daher, herauszufinden, ob unterschiedliche Bereiche von Umweltinnovationen gemessen an ihren Umweltwirkungen von unterschiedlichen Faktoren beeinflusst werden. Als Datenbasis kann hierzu die aktuelle deutsche Innovationserhebung des ZEW im Rahmen des europaweiten Innovationspanels 2009 (Community Innovation Panel, CIS) verwendet werden. Zum ersten Mal wurde in dieser Erhebung ein eigenes Modul zu Umweltinnovationen berücksichtigt, das die Analyse dieser Innovationen nach unterschiedlichen Umweltbereichen erlaubt.

Im Rahmen unserer Untersuchung werden Umweltinnovationen als Produkt-, Prozess-, Marketing- und organisationsbezogene Innovationen definiert, die zu einer deutlichen Verringerung der Umweltbelastung führen. Es spielt dabei keine Rolle, ob die Umwelteffekte Ziel der Innovationstätigkeit waren, oder lediglich als positiver Nebeneffekt resultierten.

In der einschlägigen Literatur werden die Bedeutung von Regulierungen sowie Kosteneinsparungen als Motivationen für die Durchführung von Umweltinnovationen betont. Darüber hinaus müssen jedoch viele weitere Faktoren wie die Ausstattung und Verfügbarkeit technischer Ressourcen, firmenspezifische Faktoren, organisatorische Innovationen, das Wettbewerbsumfeld sowie die Konsumnachfrage einbezogen werden.

Die empirische Analyse zeigt, dass sich die Innovationsaktivitäten mit mittleren bis hohen Umweltauswirkungen auf die Bereiche Energieverbrauch, Kohlendioxidemissionen und Recycling konzentrieren, während „etablierte“ Bereiche wie die Reduktion von Luftschadstoffen wie Schwefeldioxid oder Stickoxiden sowie der Wasserverschmutzung, die zur Zeit nicht so deutlich in der politischen Diskussion stehen, deutlich unterrepräsentiert sind.

Regulierungen sind für die meisten Umweltbereiche außer material- und energiebezogenen Prozessinnovationen von hoher Bedeutung. Besonders für End-of-pipe dominierte Bereiche wie die Reduktion von Luftemissionen wie $\mathrm{SO}_{2}$ und $\mathrm{NO}_{x}$ spielen schon existierende und auch erwartete zukünftige Regulierungen eine quantitativ wichtigere Rolle als für andere Bereiche. Für Innovationen zur Energieeinsparung sind eher Kostenersparnisse entscheidend. Umweltmanagementsysteme helfen dabei, derartige Innovationsaktivitäten auszulösen, da sie offenbar dazu beitragen, das Problem nicht funktionierender Informationsflüsse in einem Unternehmen zu lösen. In Bezug auf produktbezogene Umweltinnovationen zeigen die ökonometrischen Analysen, dass schon bestehende Regulierungen nur für Luft-, Wasser- und Lärmemissionen bzw. Bodenbelastung wichtig sind, nicht jedoch für energiesparende Produkte und Recycling. Die befragten Firmen bestätigen jedoch eine hohe Bedeutung zukünftig erwarteter Regulierungen für die Realisierung von umweltschonenden Produkten. 


\title{
Determinants of Eco-innovations by Type of Environmental Impact
}

\section{The Role of Regulatory Push/Pull, Technology Push and Market Pull}

\author{
Jens Horbach $^{1}$ \\ University of Applied Sciences Augsburg \\ Christian Rammer, Klaus Rennings \\ Centre for European Economic Research (ZEW), Mannheim
}

\begin{abstract}
Empirical analyses of the determinants of environmental innovations were rarely able to distinguish between different areas of environmental impacts. The paper tries to close this gap by employing a new and unique dataset based on the German Community Innovation Survey conducted in 2009. The main purpose of the paper is to test whether different types of eco-innovations (according to their environmental impacts) are driven by different factors. Besides a complex set of different supply, firm specific and demand factors, the literature on the determinants of environmental innovations accentuates the important role of regulation, cost savings and customer benefits. We find that current and expected government regulation is particularly important for pushing firms to reduce air (e.g. $\mathrm{CO}_{2}$, $\mathrm{SO}_{2}$ or $\mathrm{NO}_{\mathrm{x}}$ ) as well as water or noise emissions, avoid hazardous substances and increase recyclability of products. Cost savings are an important motivation for reducing energy and material use, pointing to the role of energy and raw materials prices as well as taxation as drivers for eco-innovation. Customer requirements are another important source for eco-innovations, particularly with regard to products with improved environmental performance and process innovations that increase material efficiency, reduce energy consumption and waste and the use of dangerous substances. Firms confirm a high importance of expected future regulations for all environmental product innovations.
\end{abstract}

JEL classification: Q55, O33, O38, C25

Keywords: Environmental Innovation, Environmental Impacts, Discrete Choice Models, Regulation, Cost Savings, Demand Pull, Environmental Policy

${ }^{1}$ Corresponding author: University of Applied Sciences Augsburg, P.O. Box 110605, D-86031 Augsburg, Email: jens.horbach@hs-augsburg.de 


\section{Introduction}

In recent years, a lot of research has been done to identify the determinants of environmental innovations (del Rio Gonzalez, 2009). In most econometric studies, environmental innovations in general were analysed while only a few papers distinguished between end-of-pipeinnovations and cleaner production. In the literature, there is agreement that environmental innovations are more or less regulation driven though many studies show a positive role of cost-savings as a motivation especially for cleaner production technologies (Horbach, 2008; Frondel et al., 2007). However, due to the lack of more differentiated data, the literature on driving forces of environmental innovations so far has neglected to analyse different areas of environmental impacts of eco-innovations such as recycling, low carbon technologies or innovations for water management (Kammerer, 2009). Kammerer also emphasises the role of customer benefits as a determinant for environmental innovations.

The aim of our paper is to contribute to the existing research on driving forces of environmental innovations by identifying determinants for eco-innovations targeting different areas of environmental impacts.

We use data from the German part of the Community Innovation Survey (CIS) conducted in 2009. This survey contains detailed information on environmental innovations, distinguishing between different impact areas both for process and product related eco-innovations and captures the importance of these impacts for a firm's overall contribution to reduce environmental externalities. Furthermore, the survey includes data on innovation sources, competition conditions, $R \& D$ expenditure or subsidies allowing an analysis how to improve the regulatory framework and the market opportunities of the firms operating in these areas. Identifying specific determinants of environmental innovation by area of environmental impact can help to 
formulate more detailed policy recommendations that are better fitting for different market segments.

Our paper is structured as follows: Section 2 explains definitions and gives an overview on the literature. In Section 3, our data basis and descriptive statistics are presented. Section 4 contains the results of our econometric estimations. Finally we derive some conclusions and policy recommendations.

\section{Definitions and Literature Review}

\subsection{Environmental innovation}

In this paper, we apply a definition of environmental innovation (or "eco-innovation") which is taken from a EU funded research project called „Measuring Eco-Innovation“ (MEI). This project aimed at developing a concept for measuring environmental innovations and their main determinants and impacts in large-scale international firm surveys. The MEI definition is as follows (Kemp und Pearson 2008):

"Eco-innovation is the production, application or exploitation of a good, service, production process, organizational structure, or management or business method that is novel to the firm or user and which results, throughout its life cycle, in a reduction of environmental risk, pollution and the negative impacts of resources use (including energy use) compared to relevant alternatives".

This definition shows three important features: it is based on a subjective view of innovation (i.e. the innovation has to be new for the firm), it only considers implemented innovations (rather than activities targeted at reducing environmental impacts), and it relates environmental impacts to the state of the art. 
The subjective view of innovation is fully in line with the Oslo Manual on collecting and interpreting innovation data (OECD and Eurostat, 2005) though it somewhat deviates from the traditional economic notion of innovation introduced by Schumpeter (1934) which typically regards an innovation as the first introduction of a new product, process, service or organisational structure into the market. Kemp and Pearson (2008) deviate from this view to include the adoption of innovations already introduced by others before. Including adoption to the definition of innovation implies focusing on the diffusion of technologies.

The MEI definition emphasises on results (in contrast to motivation). According to this definition it does not matter if environmental improvements have been the primary goal of a new product or process or came as a by-product or simply by chance. Eco-innovations can thus be the result of other economic rationalities such as increasing market shares or reducing costs. One may assume that many innovations leading to less environmental externalities have not been predominantly motivated by environmental concerns. While end-of-pipe technologies had only one environmental goal to be fulfilled in the past, and induced some extra-costs, the new generation of integrated environmental technologies - known as cleaner production - are complex innovation activities following more than one target.

Finally, the definition requires environmentally beneficial innovations compared to relevant (i.e. conventional) alternatives, e.g. energy saving light bulbs compared to conventional bulbs. This element of the definition ensures that eco-innovations have real effects on a firm's environmental impacts.

\subsection{Determinants of environmental innovations}

We use a simple framework for separating four groups of factors that have been found as main determinants of eco-innovations in the literature: firm strategies, technology, market and regulation (see Figure 1). In this study, we particularly focus on regulation and market forces. 
Figure 1: Determinants of eco-innovations

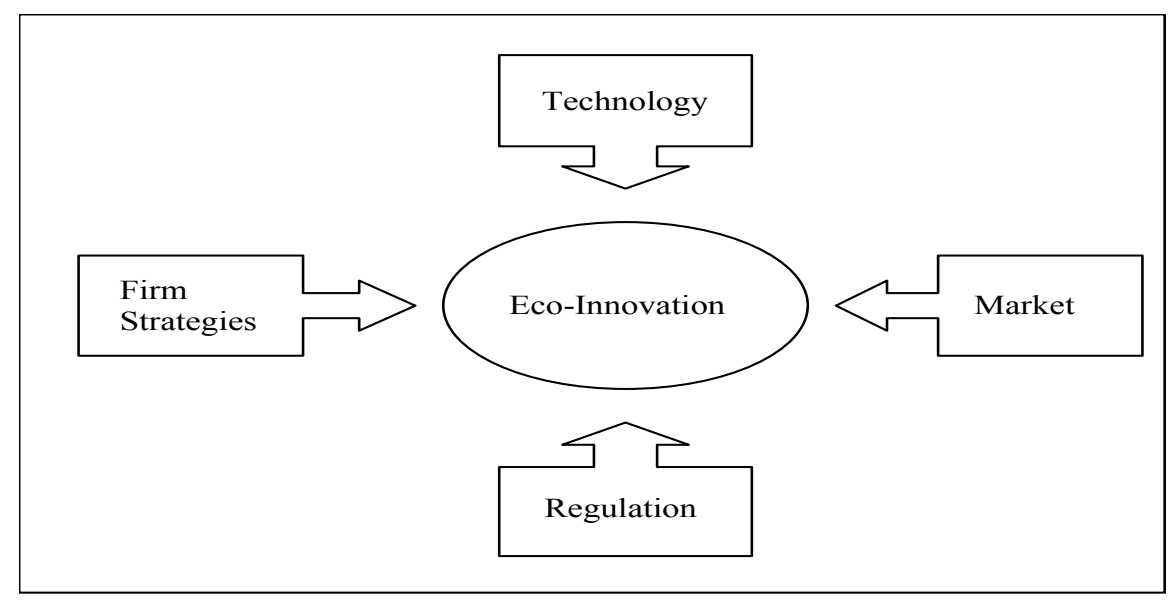

Regulation has been identified as an important determinant of environmental innovation in several empirical studies (e.g. early studies from Green et al., 1994; Cleff and Rennings, 1999; Rennings and Zwick, 2002; Brunnermeier and Cohen, 2003) and is known as the "regulatory push/pull effect” (Rennings 2000, recent overview in del Rio Gonzalez 2009). Recently, Popp (2006) found evidence in a study based on patent data from the United States, Japan and Germany that innovation decisions of companies were mainly driven by national regulation, not by regulation abroad. Del Rio Gonzalez (2005) identified regulation pressure and corporate image as the main drivers of adopting cleaner technology in a survey in the Spanish pulp and paper industry. Frondel et al. (2007) find that generally policy stringency is an increasingly important driving force for environmental innovations rather than the choice of single policy instruments - a similar result was found by Arimura et al. (2007) for the effect of regulation on green $R \& D$. Facilities facing very stringent environmental regulation are more likely to conduct environmental R\&D. Frondel et al. (2007) point to the fact that the effects of regulation may differ with regard to different environmental technology fields: Whereas end-of-pipe technologies are especially triggered by regulation, cost savings and environmental management systems seem to be more important for the introduction of cleaner technologies. 
Horbach (2008) analyses panel data and finds influence from regulation and the motivation of cost saving as main determinants.

A recent paper of Khanna et al. (2009) also distinguishes between present and anticipated environmental regulation - an issue that is also included in our econometric analysis (see Section 4). The authors find that "... anticipated regulations and the presence of "complementary assets' is important for creating the incentives and an internal capacity to undertake incremental adoption of pollution prevention techniques" (Khanna et al., 2009:85).

An important contribution to the discussion has been made by Kammerer (2009). Firstly, because he has shown that innovation effects of regulation vary by different areas of environmental impacts. Thus one should distinguish between eco-innovations that target energy and material efficiency, reducing greenhouse gas emission, improving recycling or reducing water and soil emissions. Furthermore, product and process innovations should be separated.

Secondly, Kammerer (2009) contributes to the discussion of market pull factors as determinants of environmental innovations by introducing the concept of customer benefits which is well known in the marketing literature. While regulation seems to be still necessary to overcome the double externality problem, existing studies indicate that there is not a strong stimulus for environmental innovation from the demand side since eco-friendly products are still too expensive (Rehfeld et al., 2007). While it is argued that also consumers can drive innovations (van den Bergh 2008, Brohmann et al. 2009), the argument is hardly supported by empirical evidence. Kammerer (2009) finds empirical evidence that customer benefits play a key role for environmental innovations as soon as a product delivers added value to the customer. In other words: While it may be difficult to get added value from green electricity (except if it is labelled and thus differentiated for consumers), there are certain environmental product innovations with substantial customer benefits such as food or baby clothes. Consequently, individuals' willingness to pay a premium for organic food or organic baby clothes is much 
higher than for green electricity. Finally, also environmental process innovations create customer benefits such as less water, material or energy use.

Furthermore, also supply factors play an important role for environmental innovation. On the basis of German panel data, Horbach (2008) shows that the improvement of technological capabilities ("knowledge capital") by R\&D triggers environmental innovations. Canon de Francia et al. (2007:307) find that “...availability of greater technical knowledge within the company moderates its vulnerability in the face of the demands of new environmental regulations." It is also widely agreed that proximity to the best knowledge infrastructure is one of the main drivers of R\&D investments abroad (Edler et al., 2003).

Finally, also company specific factors influence the innovation decision, such as knowledge transfer mechanisms and involvement in networks (Wagner 2009). From the perspective of the resource-based view of the firm, "green capabilities" play an important role (Hart, 1995, Kammerer, 2009). The importance of environmental management systems for ecoinnovations has been shown by Rennings et al. (2006), Rehfeld et al. (2007), Wagner (2008) and Khanna et al. (2009). Especially for the introduction of cost-saving cleaner technologies, Environmental Management Systems (EMS) seem to be very important because they help to overcome incomplete information within a firm. This aspect has also been pointed out in the literature dealing with the famous Porter-hypothesis. Following Porter and van der Linde (1995), firms do not detect the potential of environmental innovations because they are “... still inexperienced in dealing creatively with environmental issues" (Porter and van der Linde, 1995: 99). Environmentally and economically benign innovations are not realised because of incomplete information, organizational and coordination problems. Firms are not able to recognize the cost saving potentials (e.g. energy or material savings) of environmental innovation so that EMS may serve as a tool to detect the lacking information. Khanna et al. (2009) confirm this argument by accentuating the important role of a broader view of environmental 
management systems in their theoretical and empirical analysis: “... senior management commitment, team-work, empowerment of employees at all levels, and techniques such as process mapping, root cause analysis and environmental accounting can enable the firm to become aware of inefficiencies that were not recognized previously and to find new ways to increase efficiency and reduce the costs of pollution control" (Khanna et al., 2009:90). Therefore, it seems to be necessary to include indicators for the general organizational structure of a firm including organizational innovations when empirically explaining environmental innovation activities.

Existing research has shown that a firm's decision to introduce eco-innovations is influenced by a variety of factors, including technology push, market pull, policy and firm specific aspects (Horbach, 2008, 2010). Owing to a lack of more detailed data, the existing empirical literature concentrated on the analysis of determinants of environmental innovation in general. A detailed empirical distinction between different impacts was not possible. However, the different areas of environmental impacts such as energy and material use, pollution of air, water or soil, recycling or climate policies or abatement technologies reducing noise or toxic substances may be affected very differently by different types of policy interventions or market expectations. We already pointed to the fact that e.g. cleaner technologies are triggered by different motivations such as cost savings compared to end-of-pipe technologies that are mostly motivated by regulations. Furthermore, the market success may play a different role for different environmental fields. For that reasons, our paper may also be understood as an explorative empirical analysis trying to find different determinants of different environmental fields. Against this background, we want to contribute to the discussion by focusing on:

- different impacts of environmental innovations introduced by firms; (differences e.g. in determinants but also regarding the use of information sources and the competitive situation); 
- the role of market factors for introducing eco-innovations, particularly with regard to customer demand and cost savings;

- the role of both current and planned government regulation;

- impacts of eco-innovations on firm performance by different area of environmental impacts to find out which environmental fields are predominantly market driven.

\section{Data and descriptive statistics}

\subsection{Data}

Our study rests on a unique firm data set collected in the context of the Community Innovation Surveys (CIS) of the European Commission. For the CIS conducted in 2009, a separate module on environmental innovations was introduced. The module largely follows the concept for measuring eco-innovation developed in the MEI project mentioned above, though some modifications have been made to make it compatible with the basic definitions and methodologies used in the CIS. An environmental innovation has been defined as "a new or significantly improved product (good or service), process, organisational method or marketing method that creates environmental benefits compared to alternatives. The environmental benefits can be the primary objective of the innovation or the result of other innovation objectives. The environmental benefits of an innovation can occur during the production of a good or service, or during the after sales use of a good or service by the end user." In what follows is a list of environmental benefits that an environmental innovation could have produced either with the firm or from the after sales use of a product by the user for which surveyed firms should say whether this benefit has occurred or not. 
The German CIS further developed this question in two important respects. Firstly, firms reporting a certain environmental benefit were asked to assess whether this benefit was of high, medium or low importance in terms of reducing environmental impacts. Secondly, the list of potential environmental benefits has been enlarged to better distinguish different areas of environmental externalities and associated policies.

In addition, the survey asked firms whether any of these eco-innovations have been introduced in response to existing or expected environmental regulations, the availability of financial support by governments, demand from customers, or voluntary codes or industry agreements.

The German CIS of 2009 covers 7,061 firms in mining and quarrying, manufacturing, energy and water supply, and a large number of service sectors. The response rate was $26 \%$ both for manufacturing and services which is in line with comparable non-mandatory surveys. In order to control for a likely response bias between innovating and non-innovating firms, a non response survey was performed, covering a stratified random sample of more than 4,800 non responding firms. This survey was conducted by telephone and revealed that the share of innovators among non responding firms did not differ significantly from that of responding firms.

Furthermore, we also use data stemming from a telephone survey that the Centre for European Economic Research (ZEW) conducted in addition to the German CIS 2009. A subsample of 3,778 firms of the German CIS 2009 was considered, the response rate was $78 \%$ so that the answers of 2952 firms are available. The firms were considered for the additional telephone survey if they

- answered to the CIS questionnaire;

- introduced an innovation from 2006 to 2008 with at least low environmental impacts in one or several environmental fields. 
In contrast to the CIS questionnaire using the before mentioned scale of no, low, medium or high impact, the additional telephone survey only allowed a yes-no option to assess the environmental impacts of a firm's innovation. Therefore, only 1,294 firms out of the 2952 firms confirmed having introduced environmental process or product innovations from 2006 to 2008. The information from the telephone survey allows further exploring the market orientation of different environmental fields by analysing their different influence on a firm's performance (see also Section 4.2).

\subsection{Descriptive results}

Descriptive results (see Table 1) show that the innovation activities with high or medium environmental impacts concentrate on the reduction of energy and material use, $\mathrm{CO}_{2}$ emissions and recycling whereas areas such as the reduction of other air emissions or water pollution that are not in the focus of present political discussions are under-represented. This holds for process and product innovations. 
Table 1: Environmental innovations by different areas

\begin{tabular}{|c|c|c|c|c|c|}
\hline \multicolumn{6}{|c|}{ Introduction of innovations with environmental benefits within the firm 2006 to 2008} \\
\hline \multirow[t]{2}{*}{ Environmental impact areas } & \multicolumn{4}{|c|}{ In $\%$ of all firms with innovations } & \multirow{2}{*}{$\begin{array}{l}\text { Number } \\
\text { of firms }\end{array}$} \\
\hline & High & Medium & Small & No & \\
\hline Reduced material use per unit of output & 5.6 & 16.8 & 17.6 & 60.0 & 4,929 \\
\hline Reduced energy use per unit of output & 7.9 & 16.7 & 20.5 & 55.0 & 4,929 \\
\hline Reduced $\mathrm{CO}_{2}$ emissions & 7.3 & 12.6 & 15.4 & 64.8 & 4,927 \\
\hline Reduced emissions of other air pollution & 4.8 & 8.9 & 12.1 & 74.3 & 4,928 \\
\hline Reduced water pollution & 4.2 & 9.3 & 11.4 & 75.1 & 4,927 \\
\hline Reduced soil pollution & 2.4 & 5.5 & 8.5 & 83.6 & 4,927 \\
\hline Reduced noise pollution & 3.4 & 9.6 & 13.2 & 73.7 & 4,925 \\
\hline Replacement of hazardous substances & 4.4 & 9.5 & 12.0 & 74.1 & 4,928 \\
\hline Recycled waste, water or materials & 7.3 & 14.6 & 17.4 & 60.7 & 4,926 \\
\hline \multicolumn{6}{|c|}{$\begin{array}{l}\text { Introduction of innovations with environmental benefits from using a firm's products } 2006 \text { to } \\
2008\end{array}$} \\
\hline Reduced energy use & 9.1 & 15.7 & 14.0 & 61.2 & 4,886 \\
\hline Reduced air, water, soil or noiseemissions & 7.0 & 10.5 & 12.8 & 69.8 & 4,887 \\
\hline Improved recycling of products after use & 4.6 & 9.4 & 12.0 & 74.0 & 4,886 \\
\hline
\end{tabular}

Source: German CIS 2009

The firms also reported on whether certain impulses triggered their environmental innovations (see Table 2). The relative importance of the anticipation of future regulations seems to be as important as existing regulations. Only $10 \%$ of the questioned firms denote subsidies as relevant for triggering environmental innovation. Supporting the analyses of Kammerer (2009, see also Section 2) the demand of customers seems to be very relevant. 
Table 2: Impulses for environmental innovations from 2006 to 2008

\begin{tabular}{|c|c|c|c|}
\hline \multirow{2}{*}{$\begin{array}{l}\text { Environmental innovations that were } \\
\text { introduced in response to }\end{array}$} & Yes & No & \multirow{2}{*}{$\begin{array}{l}\text { Number of } \\
\text { firms }\end{array}$} \\
\hline & \multicolumn{2}{|c|}{$\begin{array}{l}\text { In } \% \text { of all firms with at } \\
\text { least weak environmental } \\
\text { impacts }\end{array}$} & \\
\hline Existing regulations & 31.5 & 68.5 & 3,733 \\
\hline Expected regulations & 27.0 & 73.0 & 3,730 \\
\hline Financial support by governments & 9.9 & 90.1 & 3,733 \\
\hline Demand from customers & 27.4 & 72.6 & 3,733 \\
\hline Voluntary codes and industry agreements & 28.0 & 72.0 & 3,727 \\
\hline
\end{tabular}

Source: German CIS 2009

The relative importance of the anticipation of future regulations seems to be as important as existing regulations (see Table 2). Only $10 \%$ of the questioned firms denote subsidies as relevant for triggering environmental innovation. Supporting the analyses of Kammerer (2009, see also Section 2) the demand of customers seems to be very relevant.

Table 3: Effects of the main environmental innovation of the firm - in \%

\begin{tabular}{|l|c|c|c|c|}
\hline Effects & Higher & No effect & Lower & Number of firms \\
\hline Change of cost & 19.6 & 43.2 & 37.2 & 1,256 \\
\hline Change of turnover & 32.4 & 65.9 & 1.7 & 1,258 \\
\hline Change of employment & 13.3 & 85.0 & 1.8 & 1,282 \\
\hline
\end{tabular}

Source: Additional telephone survey 2009

The results of the additional telephone survey (Table 3) show that the majority of ecoinnovations lead to lower or constant cost, $32 \%$ of these innovations are connected with a higher turnover so that they are also economically successful. The employment effects are also mainly positive because only $2 \%$ of the questioned firms reported a decline of employment because of their main eco-innovation - a result that is in line with a recent analysis of Horbach (2010) based on the establishment panel of the Institute for Employment Research (IAB) in Nuremberg. 


\section{Econometric analysis}

\subsection{Estimation strategy and description of variables}

To find empirical evidence to our theoretical considerations on the determinants of ecoinnovations we proceed in two steps:

Firstly, we estimate a discrete choice model detecting the specificities of environmental innovations compared to other innovation fields to establish comparability to similar analyses in the literature using older data bases (see e.g. Cleff and Rennings (1999), Rehfeld et al. (2007), Horbach (2008), Wagner (2008)).

In a second step, we restrict our analysis to firms with environmental innovations to analyze the differences between our environmental impact areas separated by process and product innovations. Do the stylized facts on the determinants of eco-innovation still hold for all environmental impacts or does, for instance, regulation only trigger selected fields?

Eco-innovations as dependent variables are measured for twelve different areas of environmental impacts. Nine refer to impacts stemming from processes in the firm while nine are related to the use of a firm's products. The nine process-related areas of environmental impacts are

- Reduced material use per unit of output

- $\quad$ Reduced energy use per unit of output

- Reduced $\mathrm{CO}_{2}$ emissions

- Reduced emissions of other air pollution

- Reduced water pollution

- Reduced soil pollution

- Reduced noise pollution

- Replacement of hazardous substances 
- Recycled waste, water, or materials

The three areas of environmental impacts from the after sales use of a product by its user are

- Reduced energy use

- Reduced air, water, soil or noise emissions

- Improved recycling of products after use

All environmental innovations must have been introduced during the three year period 2006 to 2008. In case a certain environmental impact occurred, its importance in a firm's total activities to reduce environmental externalities had to be stated on a three-point Likert scale (ranging from low to medium and high).

Since we are interested in looking at eco-innovations with a significant impact on the reduction of a firm's environmental externalities, we only consider firms as being eco-innovators as long as they report eco-innovations with medium or high importance of environmental impact. This means that we exclude firms from our definition of eco-innovation that only report innovations with a low importance for reducing their environmental impacts. ${ }^{2}$

Our correlated variables from the questionnaire of the Community Innovation Panel include a large number of variables that allow testing our theoretically derived hypotheses. We consider the following set of variables (for an exact definition and descriptive statistics see Appendix 1):

\footnotetext{
${ }^{2}$ We also tested our model by using an extended definition that included firms reporting only low importance of their innovations on environmental impacts. The results did not differ qualitatively, though most effects of our explanatory variables were less strong or sometime insignificant.
} 
- Policy measures (regulations, subsidies)

- Self-commitment of industry (as a hybrid form of regulation, neither pure regulation nor pure market push)

- Customer demand, cost savings (for market pull)

- Technology Push: Knowledge capital and infrastructure, environmental management systems, organizational innovations

- Information sources

- Cooperation

- Competition conditions

- Other control variables (e. g. sector dummies)

Regarding policy measures our questionnaire makes the difference between existing, present regulations, anticipated future regulations and the fulfillment of norms and standards (normsstandards). Furthermore, general subsidies and subsidies including tax reductions for environmental innovations (envsubsidies) are considered. Factors triggering eco-innovations are also customer demand and self-commitments of the respective branch. The role of cost savings is also explored as an important motivation of environmental innovation. Highly significant values of cost savings point to the fact that these eco-innovations are mainly market driven. Furthermore, the opening of new markets and the increase of the market share as innovation goals are included to explore this argument.

Regarding the technology push drivers, Environmental Management Systems introduced before 2006 (EMS-2006) and between 2006 and 2008 may also play an important role for improving the environmental innovative capacity of a firm (see also Section 2). Following Khanna et al. (2009), the role of general organizational innovations for the realization of process and product innovations is analyzed (see also Section 2): Influence of new methods for organizing business processes (business org), new forms of labour organizations (labour org) 
and newly organized relationships to other firms and public organizations (relation to other firms).

Further education measures measured by the further education expenses per employee may be important to improve the innovative capacities and therefore increase the knowledge capital of a firm. The innovation intensity measured by the total innovation expenses per employee shall help to explain whether environmental innovations are more R\&D intensive compared to other innovations. Further variables describing the technological capabilities of the firm such as the investment intensity, the purchase of equipment or software and the qualification level of the employees are included. We also analyze if eco-innovations predominantly rely on internal or external $R \& D$ and if the purchase of patents or other property rights plays a role. Furthermore, the importance of marketing activities for the introduction of environmental innovations is explored.

As information sources for the realization of innovations we analyse the role of internal sources denoting sources within the firm or the whole group of companies; the influence of information coming from customers and suppliers; other firms as competitors and consulters. Information for innovation activities may also be drawn from conferences and exhibitions, universities and other public research institutions, associations, patents, standardization committees and scientific journals.

To assess the relevance of cooperation activities for the realization of eco-innovations the existence of R\&D cooperations from 2006 to 2008 is considered. The variable selfcooperation describes if the eco-innovation was realized within or in cooperation with other firms. It helps to measure the influence of cooperations on the market success of ecoinnovations measured by the variable turnover effects (see Table 6). 
The competition conditions are captured by the following variables: A high risk of market entry of new competitors (market entries), a future demand that is difficult to foresee (foresee demand) and the competition intensity by foreign firms.

As control variables we used sector dummies to control for sector differences, the size and the age of the firm, dummies for innovators and East-Germany (eastwest). In Section 2 we defined eco-innovations by their environmental effects but it is also important to know in which of the different environmental fields innovations are especially motivated by the reduction of environmental impacts (envimpacts) as innovation goal in contrast to fields where market pull arguments are more important.

In a first step, we estimated ordered probit models due to the ordinal character of our dependent variables representing the environmental impacts in different areas. Because of relatively few firms in the "high" category and due to an easier interpretation of marginal effects, we also estimated binary probit models summing up the categories "high", "medium" and "small", "no effect", respectively. We decided to use the more robust results of these binary probit models because there were only marginal differences compared to the ordered probit models.

For our problem, the binary probit model can be described as follows: For each environmental field, the firm has to decide whether to innovate $(\mathrm{Y}=1)$, or not $(\mathrm{Y}=0)$. Following our theoretical considerations, we believe that different factors such as regulation, cost savings or environmental management systems summarized by a vector $\mathbf{x}$ influence this decision. Therefore, we need an estimation of the probability

$\operatorname{Prob}(\mathrm{Y}=1 \mid \mathbf{x})=\mathrm{F}(\mathbf{x}, \beta)$

Because of the binary character of our dependent variable, we use the probit model assuming the normal distribution: $\operatorname{Prob}(\mathrm{Y}=1 \mid \mathbf{x})=\varphi\left(\mathbf{x}^{\prime} \beta\right)$ 
The parameters $\beta$ reflect the impact of changes in $\mathrm{x}$ on the probability (Greene, 2008: 772).

We calculate marginal effects that allow comparing the different environmental innovation areas. For each environmental innovation area we estimated a probit model, and further divided between product and process innovation.

\subsection{Results for the determinants of eco-innovations versus other innovations}

In a first step, we explore the specificities of environmental innovations compared to other innovations (see Table 4). ${ }^{3}$ In line with former similar analyses, we observe a strong influence of regulation on eco-innovations (see Section 2). Regulations are significantly more important for eco-innovations compared to other innovations. Furthermore, cost savings especially trigger eco-innovations - a widespread result of the respective literature. ${ }^{4}$

\footnotetext{
${ }^{3}$ Different to our analysis comparing different environmental fields, we cannot use the question on direct determinants of eco-innovations (fulfillment of regulations, subsidies, demand etc.) because this question is restricted to eco-innovations. Therefore, we use the innovation goal "fulfillment of laws and regulations" as a proxy for the influence of regulation activities for this model comparing eco-innovations to other innovations.

${ }^{4}$ See also Rave et al. (2011) for a very recent analysis confirming this result.
} 
Table 4: Determinants of eco-innovations compared to other innovations

\begin{tabular}{|c|c|c|c|c|}
\hline \multicolumn{5}{|c|}{ Dependent variable: EcoInnovation } \\
\hline 1 & \multicolumn{4}{|c|}{$\begin{array}{l}\text { Innovations with high or medium environmental effects in at least one environ- } \\
\text { mental innovation field }\end{array}$} \\
\hline 0 & \multicolumn{4}{|c|}{ Innovations with only low or no environmental effects } \\
\hline \multicolumn{5}{|c|}{ Correlates } \\
\hline \multicolumn{2}{|c|}{ Policy measures } & & Information sources & \\
\hline \multicolumn{2}{|c|}{ Regulation } & $0.09(2.46)^{* *}$ & Customers & $-0.03(-1.23)$ \\
\hline \multicolumn{2}{|c|}{ NormsStandards } & $-0.02(-0.56)$ & Suppliers & $0.06(1.81)^{+}$ \\
\hline \multicolumn{2}{|c|}{ GeneralSubsidies } & $0.05(1.67)^{+}$ & $\begin{array}{l}\text { Universities, Public } \\
\text { Research }\end{array}$ & $0.06(1.53)$ \\
\hline \multirow{2}{*}{\multicolumn{2}{|c|}{ Market pull }} & & Patents & $0.04(0.66)$ \\
\hline & & & Standardization & $0.02(0.48)$ \\
\hline \multicolumn{2}{|c|}{ Cost savings } & $0.25(9.77)^{* *}$ & & \\
\hline \multicolumn{2}{|c|}{ New Markets } & $-0.01(-0.27)$ & Cooperation & \\
\hline \multirow{2}{*}{\multicolumn{2}{|c|}{ Market share }} & $0.00(0.02)$ & & \\
\hline & & & Coop & $0.05(1.90)^{+}$ \\
\hline \multicolumn{5}{|c|}{ Technology push } \\
\hline & & & Competition & \\
\hline \multicolumn{2}{|c|}{ Innovation Intensity } & $0.00(2.19)^{*}$ & & \\
\hline \multicolumn{2}{|c|}{ Internal R\&D } & $0.04(1.56)$ & Market entries & $0.03(1.65)^{+}$ \\
\hline \multicolumn{2}{|c|}{ External R\&D } & $-0.01(-0.22)$ & Foresee demand & $0.02(1.20)$ \\
\hline \multicolumn{2}{|c|}{ Purchase of patents } & $-0.04(-1.53)$ & Competition intensity & $-0.00(-0.08)$ \\
\hline \multicolumn{2}{|c|}{ EquipmentSoftware } & $0.14(5.97)^{* *}$ & & \\
\hline \multicolumn{2}{|c|}{ Marketing activities } & $0.06(2.57)^{* *}$ & Control variables & \\
\hline \multicolumn{2}{|c|}{ Qualification } & $-0.00(-3.92)^{* *}$ & & \\
\hline \multicolumn{2}{|c|}{ EMS 2006} & $0.17(5.86)^{* *}$ & Size & $0.00(1.72)^{+}$ \\
\hline \multicolumn{2}{|c|}{ Business org. } & $0.06(3.13)^{* *}$ & Age & $0.00(0.04)$ \\
\hline \multicolumn{2}{|c|}{ Labour org. } & $0.06(2.78)^{* *}$ & EastWest & $-0.02(-1.12)$ \\
\hline \multicolumn{2}{|c|}{ Relation to other firms } & $0.04(1.97)^{*}$ & Innovator & $-0.04(-1.09)$ \\
\hline \multicolumn{5}{|c|}{$\begin{array}{l}\text { Probit regression reporting marginal effects. Number of observations: } 3,606 . \text { Z-statistics are given in } \\
\text { parentheses. LR } \mathrm{Chi}^{2}(62)=742 . \text { Pseudo } \mathrm{R}^{2}=0.15 .^{+, * * * *} \text { denote significance at the } 10 \%, 5 \% \text { and } 1 \% \\
\text { level, respectively. }\end{array}$} \\
\hline \multicolumn{5}{|c|}{$\begin{array}{l}\text { The marginal effects for the continuous independent variables were calculated at their means. Concerning } \\
\text { dummy variables the values report the change in probability for a discrete change of the dummy variable } \\
\text { from } 0 \text { to } 1 \text {. Sector dummies are not reported. }\end{array}$} \\
\hline \multicolumn{5}{|c|}{ Innovators are all firms with product, process, organizational or marketing innovations. } \\
\hline
\end{tabular}

Source: German CIS 2009

As a relatively new technology field (e. g. the solar cell industry in East-Germany), ecoinnovations are characterised by higher innovation intensity, consequently the purchase of 
new equipment and software and marketing activities are more important compared to other innovations. On the other side, other innovations rely more on their internal human capital capacities documented by the significant negative influence of the variable qualification.

The observation that the environmental sector is still a relatively young and dynamic field is also confirmed by the significantly positive influence of the variable market entries denoting fragile market positions because of probable market entries of new competitors. Ecoinnovators are also more likely to cooperate with other firms (positive influence of coop).

Environmental Management Systems (EMS 2006) significantly trigger eco-innovations but also general organizational changes such as new forms of labour organization or quality or supply chain management are highly correlated to eco-innovations supporting Khanna et al. (2009) and further theoretical considerations pointed out in Section 2.

\subsection{Results for differences between different environmental impacts}

In a second step, we enlarge our analysis by differentiating between different environmental technology fields. The results of our probit models reporting marginal effects for each environmental innovation areas are summarized in Table 5 a) and b).

\section{Environmental innovations within the firm (process innovations)}

Except the field "reduced material and energy use" regulations seem to be important for all environmental areas as expected from earlier analyses. Nevertheless, our analysis reveals some interesting new insights: For typically end-of-pipe oriented areas such as other air emissions $\left(\mathrm{SO}_{2}\right.$ or $\left.\mathrm{NO}_{\mathrm{x}}\right)$ the marginal effects for present $(8.4 \%)$ and future $(8.8 \%)$ regulations are higher than for other areas. For energy savings cost savings are the main motivation. On the other side, cost savings do not play a dominant role for water, soil, noise or dangerous substances. That confirms the view that areas such as material or energy savings and the reduc- 
tion of $\mathrm{CO}_{2}$ emissions dominated by cleaner technologies are more likely to be also economically benign compared to the other areas.

Material and energy savings are accompanied by changes in the organization of labour (e.g. realignment of departments) whereas for water, soil and noise not internal organizational changes but the relation to other firms and customers seems to be relevant.

Subsidies are quantitatively very important for $\mathrm{CO}_{2}$ emissions - in fact a relatively young innovation area that still highly depends on basic research activities that have to be financed by public funds. Self-commitments are relevant for all environmental innovation areas, they are quantitatively most important for recycling. This is due to the German tradition of negotiated agreements in the area recycling resp. circular economy, regulation is often based on take-back agreements with firms. The reduction of environmental impacts as motivation especially triggers $\mathrm{CO}_{2}$ and other air emission innovations.

Concerning information sources the differences between different environmental innovation areas are only small, in fact, there are only few significant coefficients. This is also the case for competition conditions - a sign that the differences between the different innovation areas according to this aspect seem to be rather small. 
Table 5: Determinants of eco-innovation by different environmental areas

a) Eco-innovations within the firm

\begin{tabular}{|c|c|c|c|c|c|c|c|c|c|}
\hline Determinants & $\begin{array}{l}\text { Mate- } \\
\text { rial }\end{array}$ & Energy & $\mathrm{CO}_{2}$ & $\begin{array}{l}\text { Other } \\
\text { Air }\end{array}$ & Water & Soil & Noise & $\begin{array}{l}\text { Dang. } \\
\text { substances }\end{array}$ & Recyc. \\
\hline $\begin{array}{l}\text { Present regula- } \\
\text { tions }\end{array}$ & - & - & 5.1 & 8.4 & 5.7 & - & 4.1 & 9.1 & 5.2 \\
\hline Future regulations & - & - & 7.3 & 8.8 & 3.4 & 5.4 & 7.2 & 7.0 & 8.6 \\
\hline Env. Subsidies & - & - & 19.4 & 7.3 & - & - & - & -4.4 & - \\
\hline Demand & 5.4 & 5.7 & 3.8 & - & - & - & - & 5.1 & 6.0 \\
\hline Self commitment & 8.9 & 9.6 & 6.9 & 4.7 & 8.7 & 5.8 & 6.3 & 3.7 & 12.0 \\
\hline EMS - 2006 & 7.8 & 6.8 & 4.6 & 3.8 & 3.8 & - & 3.7 & 4.3 & 6.8 \\
\hline EMS 2006-2008 & - & 6.4 & 9.1 & 8.0 & 7.0 & - & 4.3 & 7.2 & 7.0 \\
\hline Cost savings & 19.7 & 24.8 & 11.7 & 5.5 & - & - & - & - & 6.5 \\
\hline $\begin{array}{l}\text { Reduction Env. } \\
\text { Impacts }\end{array}$ & 12.4 & 11.0 & 26.3 & 21.6 & 11.8 & 9.3 & 12.1 & 12.2 & 8.4 \\
\hline Size of the firm & - & 0.0 & 0.0 & - & - & - & - & - & - \\
\hline Age of the firm & - & - & -0.0 & -0.0 & - & -0.0 & - & - & \\
\hline East West & - & - & -6.0 & -4.7 & -4.8 & -2.7 & - & -4.1 & \\
\hline Innovation Intens. & - & - & - & - & 0.0 & 0.0 & 0.0 & - & 0.0 \\
\hline Internal R\&D & - & - & - & 3.5 & - & -3.1 & - & - & - \\
\hline External R\&D & - & -4.6 & - & - & - & - & - & -4.2 & -4.9 \\
\hline Cooperation & - & - & - & - & - & - & - & 5.5 & - \\
\hline \multicolumn{10}{|l|}{ Info Sources } \\
\hline Internal sources & - & - & - & - & - & - & 3.5 & - & 4.0 \\
\hline Customers & - & -4.1 & - & - & - & - & - & - & - \\
\hline Competitors & - & - & -7.1 & - & - & - & - & - & -5.7 \\
\hline Exhibitions, conf. & -6.1 & - & - & - & - & - & - & - & - \\
\hline Universities & 10.0 & 8.3 & - & - & - & - & - & - & 8.1 \\
\hline Patents & 10.4 & - & - & - & - & - & - & - & - \\
\hline \multicolumn{10}{|l|}{ Org. innovation } \\
\hline Business org. & - & - & - & - & - & - & 4.2 & - & - \\
\hline Labour org. & 6.5 & 4.8 & - & - & - & - & - & - & 3.7 \\
\hline $\begin{array}{l}\text { Relation to other } \\
\text { firms }\end{array}$ & - & - & - & - & 6.1 & 3.4 & 3.3 & - & 4.6 \\
\hline \multicolumn{10}{|c|}{$\begin{array}{l}\text { Marginal effects are reported (in \%). The marginal effects for the continuous independent variables } \\
\text { were calculated at their means. Concerning dummy variables the values report the change in probabil- } \\
\text { ity for a discrete change of the dummy variable from } 0 \text { to } 1 \text {. Only significant marginal effects (at least } \\
\text { at } 10 \% \text { level) are considered. "-" means that the marginal effect is not significant. }\end{array}$} \\
\hline
\end{tabular}

Source: German CIS 2009 
b) Product innovations

\begin{tabular}{|l|c|c|c|}
\hline Determinants & $\begin{array}{l}\text { Energy consump- } \\
\text { tion }\end{array}$ & $\begin{array}{l}\text { Emission reductions air, } \\
\text { water, soil, noise }\end{array}$ & Recycling \\
\hline Present regulations & - & 3.6 & - \\
\hline Future regulations & 11.1 & 10.5 & 10.7 \\
\hline EnvSubsidies & 17.9 & 11.2 & -6.9 \\
\hline Demand & 7.7 & 16.2 & 11.3 \\
\hline Self commitment & 13.6 & 4.4 & - \\
\hline $\begin{array}{l}\text { Cost savings } \\
\text { Product quality }\end{array}$ & 4.5 & - & - \\
\hline Reduction Env. Impacts & 10.6 & 21.9 & - \\
\hline $\begin{array}{l}\text { Org. } \text { innovation } \\
\text { Business org. }\end{array}$ & 6.6 & - & - \\
$\begin{array}{l}\text { Labour org. } \\
\text { Relation to other firms }\end{array}$ & - & - & 6.7 \\
\hline $\begin{array}{l}\text { Marginal effects are reported (in \%). The marginal effects for the continuous independent varia- } \\
\text { bles were calculated at their means. Concerning dummy variables the values report the change in } \\
\text { probability for a discrete change of the dummy variable from 0 to 1. Only significant marginal } \\
\text { effects (at least at 10\% level) are considered. }\end{array}$ \\
\hline
\end{tabular}

Source: German CIS 2009

\section{Results for product innovations}

Concerning environmental product innovations our econometric results show that present regulations are only significant for reductions of air, water, soil and noise emissions but not for the other two regarded areas (energy consumption and recycling) but the firms expect a growing importance of future regulations for all product innovations. In all considered environmental innovation areas future regulations already trigger innovations. Not surprisingly, the demand is quantitatively important for all areas and especially for energy consumption where the demand is driven by the renewable energy law. Whereas subsidies are an important determinant of energy and emission reduction products they are significantly negatively correlated to recycling products, the respective marginal effect amounts to $-7 \%$. For this innovation field, self-commitments seem to be more important, also connected with a positive marketing effect for the firm. 
Contrary to process innovations, environmental management systems do not play an important role for environmental product innovations. For energy saving products organizational innovations such as quality management and supply chain management and relations to other firms are important showing that these product innovations may only be realized in close cooperation with all actors of the value chain.

Concerning information sources and competition conditions there were only few significant coefficients pointing to the fact that the differences between our three product innovation fields are not so important with respect to these variables.

The previous results point to the fact that the potential market success of eco-innovations is an important variable constituting differences between the various eco-innovation fields. In fact, it is important to know whether environmental innovations may be triggered by stricter regulations or rather by the improvement of market conditions. The use of the data of the aforementioned additional telephone survey allows exploring this important aspect in more detail. We try to find out which environmental innovations are more market-driven compared to other areas that are more likely to be triggered by regulations. Therefore, we estimate a binary probit model with the turnover effects of environmental innovation activities as dependent variable (see Table 6). 
Table 6: Turnover effects of environmental innovations

\begin{tabular}{|c|c|c|c|}
\hline \multicolumn{4}{|c|}{$\begin{array}{l}\text { Dependent variable: Turnover effects } \\
1 \text { Increase of turnover because of the main environmental innovation } \\
0 \text { Constant or decreasing turnover }\end{array}$} \\
\hline \multicolumn{4}{|c|}{ Correlates } \\
\hline $\begin{array}{l}\text { Eco-innovations within } \\
\text { the firm } \\
\text { Material use } \\
\text { Energy use } \\
\mathrm{CO}_{2} \text {-emissions } \\
\text { Other air emissions } \\
\text { Water pollution } \\
\text { Soil pollution } \\
\text { Noise } \\
\text { Dangerous substances } \\
\text { Recycling of material, } \\
\text { waste and water }\end{array}$ & $\begin{array}{l}0.11(2.67)^{* *} \\
-0.08(-1.79)^{+} \\
0.02(0.50) \\
0.02(0.44) \\
0.04(0.67) \\
-0.03(-0.44) \\
-0.04(-0.78) \\
-0.03(-0.58) \\
-0.09(-2.20)^{*}\end{array}$ & $\begin{array}{l}\text { Product innovations } \\
\text { Energy saving prod. } \\
\text { Emissions (air, wa- } \\
\text { ter, soil, noise) } \\
\text { Recycling } \\
\text { Control variables } \\
\text { Size } \\
\text { Self-Cooperation } \\
\text { Internal research } \\
\text { Further education } \\
\text { Investment intensity } \\
\text { Competition intensi- } \\
\text { ty }\end{array}$ & $\begin{array}{l}0.0(0.07) \\
0.14(3.56)^{* *} \\
0.09(2.19)^{*} \\
0.09(2.51)^{* *} \\
0.00(2.29)^{*} \\
-0.09(-2.36)^{*}\end{array}$ \\
\hline \multicolumn{4}{|c|}{$\begin{array}{l}\text { Probit regression reporting marginal effects. Number of observations: } 872 \text {. Z-statistics } \\
\text { are given in parentheses. LR Chi }{ }^{2}(38)=144 \text {. Pseudo } \mathrm{R}^{2}=0.13 .^{+*},{ }^{* * *} \text { denote signifi- } \\
\text { cance at the } 10 \%, 5 \% \text { and } 1 \% \text { level, respectively. } \\
\text { The marginal effects for the continuous independent variables were calculated at their } \\
\text { means. Concerning dummy variables the values report the change in probability for a } \\
\text { discrete change of the dummy variable from } 0 \text { to } 1 \text {. Sector dummies are not reported. }\end{array}$} \\
\hline
\end{tabular}

Source: German CIS 2009

The results show that material savings within the firm and energy saving products led to an increase of turnover whereas energy saving activities seem to rise costs in the short run and therefore leading to a decrease of turnover. This observation may not be a contradiction to our afore-mentioned results where cost savings are a determinant of the introduction of energy saving measures within the firm because in the short run we observe higher cost because of high investments but cost savings in the long run because of lower energy use.

A further interesting result is that the improvement of the recyclability of products significantly reduces turnover because of higher cost within the firm. 
The econometric results for further control variables show that internal $R \& D$, high investment intensity and an improvement of the innovative capacities of the firm trigger the economic success of the eco-innovation. Furthermore, especially firms that predominantly developed the eco-innovation itself or in cooperation with other firms are economically successful.

\section{Summary and Conclusions}

Up to now, empirical analyses on the determinants of environmental innovations were rarely able to distinguish between different environmental areas such as the reduction on energy use, air, water or soil pollution. The paper tries to close this gap by using a new and unique database of the German part of the Community Innovation Panel (CIS) 2009. This panel wave of the CIS contained, for the first time, a special module on eco-innovation allowing analyzing environmental innovations by different areas. We complemented our analysis by results of an additional telephone survey conducted by ZEW in 2009 using a subsample of the German CIS.

Within our analysis, we define environmental innovations as product, process, marketing and organizational innovations leading to a noticeable reduction of environmental burdens. Positive environmental effects can be explicit goals or side-effects of innovations. They can occur within the respective firms or by using products or services by the customers.

The literature on the determinants of environmental innovations accentuates the important role of regulation, furthermore cost savings as motivation trigger eco-innovations. In fact, a complex set of supply factors such as the endowment and availability of technological resources, company specific factors (e. g. knowledge transfer mechanisms), organizational innovations, competition conditions and policy variables have to be included in the analysis. In the recent literature, the role of customer demand has been emphasized, too. 
Descriptive results of our empirical analysis show that the innovation activities with high or medium environmental impacts concentrate on the reduction of energy use, $\mathrm{CO}_{2}$ emissions and recycling whereas "older" areas such as the reduction of other air emissions or water pollution that are not in the focus of present political discussions are under-represented. The majority of eco-innovations $(80.4 \%)$ lead to lower or constant cost, $32 \%$ of these innovations are connected with a higher turnover so that they are also economically successful.

In a first step, we analyzed the determinants of environmental innovations compared to other innovations. In line with former similar analyses, we observe a strong influence of regulation on eco-innovations. Furthermore, cost savings especially trigger eco-innovations - a widespread result of the respective literature.

In a second step, we restrict our analyses to those firms that realized eco-innovations. For each environmental field further divided between process and product innovations, we estimated separate probit models reporting marginal effects that allow a comparison of the results.

In fact, except for material and energy reduction process innovation regulations seem to be important for all environmental areas as expected from earlier analyses. Nevertheless, our analysis reveals some interesting new in-sights: For typically end-of-pipe oriented areas such as other air emissions $\left(\mathrm{SO}_{2}\right.$ or $\left.\mathrm{NO}_{\mathrm{x}}\right)$ the marginal effects for present and future regulations are higher than for other areas. For energy consumption cost savings are the main motivation. Environmental Management Systems (EMS) seem to be especially important tools to trigger these cost-saving cleaner technologies because they help to overcome incomplete information within a firm. Subsidies are quantitatively very important for $\mathrm{CO}_{2}$ emissions - in fact a relatively young innovation area that still highly depend on basic research activities that have to be financed by public funds. 
Concerning environmental product innovations, our econometric results show that present regulations are only significant for air, water, soil and noise emissions but not for the other two regarded areas (energy consumption and recycling) but the firms expect a growing importance of future regulations for all environmental product innovations.

To explore the market orientation of the different environmental areas, we estimate a probit model capturing the turnover effects of different environmental innovations. The results show that material savings within the firm and energy saving products led to an increase of turnover. A further interesting result is that the improvement of the recyclability of products significantly reduces turnover because of higher cost within the firm. The other regarded environmental areas do not show significant effects on turnover.

Our results show that the different areas of environmental impact need different policy approaches. Fields such as material and energy savings do not need strict regulatory approaches because of their (potential) economic benefits. Nevertheless, these benefits are not automatically observed and realised by the firms because of organisational, control and coordination problems. For these fields soft instruments such as environmental management systems in connection with further organisational innovations are good tools to overcome these problems. Contrary to that, other fields such as the replacement of dangerous substances or noise reduction normally leading to higher costs still need strict environmental regulation measures. 


\section{References}

Arimura, T., A. Hibiki, N. Johnstone (2007), An Empirical Study of Environmental R\&D: What encourages Facilities to be Environmentally Innovative?, in: Nick Johnstone: Environmental Policy and Corporate Behaviour. Edgar Elgar, 142-173.

Brohmann, B., S. Heinzle, K. Rennings, J. Schleich, R. Wüstenhagen (2009), What's Driving Sustainable Energy Consumption? A Survey of the Empirical Literature, ZEW Discussion Paper 09-013, Mannheim.

Brunnermeier, S. B., M. A. Cohen (2003), Determinants of Environmental Innovation in US Manufacturing Industries, Journal of Environmental Economics and Management, Vol. 45, No. 2, 278-293.

Canon de Francia, J., C. Garces-Ayerbe, M. Ramirez-Aleson (2007), Are more innovative firms less vulnerable to new environmental regulation? Environmental and Resource Economics 36, 295-311.

Cleff, T., K. Rennings (1999), Determinants of Environmental Product and Process Innovation - Evidence from the Mannheim Innovation Panel and a Follow-Up Telephone Survey, European Environment, Vol. 9, No. 5, 191-201.

Del Rio Gonzalez, P. (2005), Analysing the Factors Influencing Clean Technology Adoption: A Study of the Spanish Pulp and Paper Industry, Business Strategy and the Environment, Vol. 14, 2005, 20-37.

Del Rio Gonzalez, P. (2009), The empirical analysis of the determinants for environmental technological change: A research agenda, Ecological Economics, Vol. 68, 861-878.

Edler, J., R. Döhrn, M. Rothgang (2003), Internationalisierung industrieller Forschung und grenzüberschreitendes Wissensmanagement. PhysicaVerlag, Heidelberg.

Frondel, M., J. Horbach, K. Rennings (2007), End-of-Pipe or Cleaner Production? An Empirical Comparison of Environmental Innovation Decisions Across OECD Countries, Business Strategy and the Environment, Vol. 16 No. 8, 571-584.

Green, K., A. McMeekin, A. Irwin (1994), Technological trajectories and R\&D for Environmental Innovation in UK Firms, Futures Vol. 26, 1047-1059.

Greene, W. H. (2008), Econometric Analysis, Sixth Edition, Pearson International, New Jersey.

Hart, S. L. (1995), A natural resource-based view of the firm, Academy of Management Review 20 (4), 986-1014.

Horbach, J. (2008), Determinants of Environmental Innovation - New Evidence from German Panel Data Sources, Research Policy, Vol. 37, 163-173. 
Horbach, J. (2010), The Impact of Innovation Activities on Employment in the Environmental Sector - Empirical Results for Germany at the Firm Level, in: Jahrbücher für Nationalökonomie und Statistik/Journal of Economics and Statistics, Vol. 230/4, 403-419.

Kammerer, D. (2009), The effects of customer benefit and regulation on environmental product innovation. Empirical evidence from appliance manufacturers in Germany, Ecological Economics, Vol. 68, 2285-2295.

Kemp, R., P. Pearson (2008), Final report MEI project about measuring eco-innovation, Maastricht, www.merit.unu.edulMEI.

Khanna, M., G. Deltas, D. R. Harrington (2009), Adoption of Pollution Prevention Techniques: The Role of Management Systems and Regulatory Pressures, Environmental and Resource Economics 44, 85-106.

OECD and Eurostat (2005), Oslo Manual Guidelines for Collecting and Interpreting innovation data, third edition, Paris, Luxemburg.

Popp, D. (2006), International Innovation and Diffusion of Air Pollution Control Technologies: The Effects of $\mathrm{NO}_{\mathrm{x}}$ and $\mathrm{SO}_{2}$ Regulation in the US, Japan, and Germany, Journal of Environmental Economics and Management, Vol. 51 No. 1, 46-71.

Porter, M. E., C. van der Linde (1995), Toward a New Conception of the EnvironmentCompetitiveness Relationship, Journal of Economic Perspectives 9, No. 4, 97-118.

Rave, T., F. Goetzke, M. Larch (2011), The Determinants of Environmental Innovations and Patenting: Germany Reconsidered, Ifo Working Paper No. 97, February 2011.

Rehfeld K., K. Rennings and A. Ziegler (2007), Determinants of Environmental Product Innovations and the Role of Integrated Product Policy - An Empirical Analysis, Ecological Economics, Vol. 61, 91-100.

Rennings, K. (2000), Redefining Innovation - Eco-Innovation Research and the Contribution from Ecological Economics, Ecological Economics, Vol. 32, 319-332.

Rennings, K., A. Ziegler, K. Ankele, E. Hoffmann (2006), The Influence of Different Characteristics of the EU Environmental Management and Auditing Scheme on Technical Environmental Innovations and Economic Performance, Ecological Economics, Vol. 57 (1), 45-59.

Rennings, K., T. Zwick (2002), The Employment Impact of Cleaner Production on the Firm Level - Empirical evidence from a Survey in Five European Countries; International Journal of Innovation Management (IJIM), Special Issue on "The Management of Innovation for Environmental Sustainability", Vol. 6 (2002), Nr. 3, 319-342.

Schumpeter, J. A. (1934), The Theory of Economic Development, Harvard University Press, Cambridge.

Van den Bergh, J. C. J. M. (2008), Environmental regulation of households: An empirical review of economic and psychological factors, Ecological Economics, Vol. 66, 559-574. 
Wagner, M. (2008), Empirical influence of environmental management on innovation: evidence from Europe, Ecological Economics, Vol. 66 (2-3), 392-402.

Wagner, M. (2009), Erfolgsfaktoren für Nachhaltigkeitsinnovationen: Qualitative und quantitative Befunde, Zeitschrift für Umweltpolitk und Umweltrecht (ZfU) 2/2009, 179-198. 


\section{Appendix 1: Definition of variables and descriptive statistics}

\begin{tabular}{|c|c|c|c|}
\hline Name of variable & Description & Mean & $\begin{array}{l}\text { Std. } \\
\text { Dev. }\end{array}$ \\
\hline $\begin{array}{l}\text { EcoInnovation } \\
\text { Eco-innovations within } \\
\text { the firm by areas }\end{array}$ & $\begin{array}{l}1 \text { Environmental innovators: realization of innovations with high or } \\
\text { medium environmental effects, } 0 \text { Other innovators }\end{array}$ & 0.47 & 0.50 \\
\hline Material use & 1 High or medium reduction of material use, 0 Other innovators & 0.23 & 0.42 \\
\hline Energy use & 1 High or medium reduction of energy use, 0 Other innovators & 0.25 & 0.43 \\
\hline $\mathrm{CO}_{2}$-emissions & 1 High or medium reduction of $\mathrm{CO}_{2}$ emissions, 0 Other innovators & 0.20 & 0.40 \\
\hline Other air emissions & 1 High or medium reduction of other air emissions, 0 Other innovators & 0.14 & 0.35 \\
\hline Water pollution & 1 High or medium reduction of water pollution, 0 Other innovators & 0.14 & 0.35 \\
\hline Soil pollution & 1 High or medium reduction of soil pollution, 0 Other innovators & 0.08 & 0.28 \\
\hline Noise & 1 High or medium reduction of noise pollution, 0 Other innovators & 0.14 & 0.34 \\
\hline Dangerous substances & $\begin{array}{l}1 \text { High or medium replacement of dangerous substances, } 0 \text { Other inno- } \\
\text { vators }\end{array}$ & 0.15 & 0.35 \\
\hline Recycling & $\begin{array}{l}1 \text { High or medium improvement of recycling of material, waste and } \\
\text { water, } 0 \text { Other innovators }\end{array}$ & 0.23 & 0.42 \\
\hline Product innovations & & & \\
\hline Energy saving prod. & 1 High or medium reduction of energy use, 0 Other innovators & 0.25 & 0.43 \\
\hline $\begin{array}{l}\text { Emissions (air, water, } \\
\text { soil, noise) }\end{array}$ & $\begin{array}{l}1 \text { High or medium reduction of air, water, soil, noise emissions, } 0 \text { Other } \\
\text { innovators }\end{array}$ & 0.18 & 0.38 \\
\hline Recycling & $\begin{array}{l}1 \text { High or medium improvement of recycling of material, waste and } \\
\text { water, } 0 \text { Other innovators }\end{array}$ & 0.14 & 0.35 \\
\hline Turnover effects & $\begin{array}{l}1 \text { Increase of turnover because of eco-innovation, } 0 \text { Decrease or con- } \\
\text { stant turnover }\end{array}$ & 0.32 & 0.47 \\
\hline Policy measures & & & \\
\hline Regulation & Fulfilment of laws and regulations ( 1 highly relevant, 0 other) & 0.17 & 0.38 \\
\hline Present regulations & Fulfillment of present laws and standards ( 1 yes, 0 no) & 0.32 & 0.47 \\
\hline Future regulations & Anticipation of future regulations ( 1 yes, 0 no) & 0.27 & 0.44 \\
\hline NormsStandards & Fulfilment of norms and standards ( 1 highly relevant, 0 other) & 0.18 & 0.38 \\
\hline GeneralSubsidies & Subsidies from German ministries or the EU ( 1 yes, 0 no) & 0.21 & 0.40 \\
\hline $\begin{array}{l}\text { EnvSubsidies } \\
\text { Market pull }\end{array}$ & Public support of eco-innovations ( 1 yes, 0 no) & 0.10 & 0.30 \\
\hline Demand & Customer demand for eco-innovations ( 1 yes, 0 no) & 0.27 & 0.45 \\
\hline Self commitment & Self commitments of the branch ( 1 yes, 0 no) & 0.28 & 0.45 \\
\hline Cost savings & Reduction of material or energy cost ( 1 highly relevant, 0 other) & 0.17 & 0.38 \\
\hline New Markets & Opening up of new markets ( 1 highly relevant, 0 other) & 0.34 & 0.47 \\
\hline $\begin{array}{l}\text { Market share } \\
\text { Technology push }\end{array}$ & Increase of the market share ( 1 highly relevant, 0 other) & 0.34 & 0.47 \\
\hline Innovation Intensity & Total innovation expenditure 2008 per employee & 16.97 & 66.28 \\
\hline Investment intensity & Gross investment 2008 per employee & 20.40 & 69.70 \\
\hline Internal R\&D & Internal R\&D (1 yes, 0 no) & 0.51 & 0.50 \\
\hline External R\&D & External R\&D ( 1 yes, 0 no $)$ & 0.23 & 0.42 \\
\hline Purchase of patents & Purchase of patents or other property rights ( 1 yes, 0 no) & 0.24 & 0.43 \\
\hline EquipmentSoftware & Purchase of equipment or software ( 1 yes, 0 no) & 0.55 & 0.50 \\
\hline Marketing activities & Internal or external marketing activities ( 1 yes, 0 no) & 0.35 & 0.48 \\
\hline Qualification & Share of employees with university degree 2008 in \% & 22.06 & 25.43 \\
\hline Further Education & Expenditure for further education per employee in 2008 & 1.22 & 6.52 \\
\hline EMS 2006 & $\begin{array}{l}\text { Introduction of an Environmental Management System (EMS) before } \\
2006 \text { ( } 1 \text { yes, } 0 \text { no) }\end{array}$ & 0.15 & 0.35 \\
\hline
\end{tabular}




\begin{tabular}{|c|c|c|c|}
\hline EMS 2006-2008 & Introduction of an EMS between 2006 and 2008 ( 1 yes, 0 no) & 0.08 & 0.27 \\
\hline Business org. & New methods for organizing business processes ( 1 yes, 0 no) & 0.43 & 0.50 \\
\hline Labour org. & New forms of labour organization ( 1 yes, 0 no) & 0.39 & 0.49 \\
\hline Relation to other firms & Newly organized relationships to other firms ( 1 yes, 0 no) & 0.25 & 0.43 \\
\hline \multicolumn{4}{|l|}{ Information sources } \\
\hline Internal sources & Sources within the firm ( 1 highly relevant, 0 other) & 0.44 & 0.50 \\
\hline Customers & Customers or clients (1 highly relevant, 0 other) & 0.37 & 0.48 \\
\hline Suppliers & Suppliers (1 highly relevant, 0 other) & 0.11 & 0.31 \\
\hline Competitors & Competitors, other firms ( 1 highly relevant, 0 other) & 0.13 & 0.34 \\
\hline Consulters & Consulters( 1 highly relevant, 0 other $)$ & 0.04 & 0.20 \\
\hline Universities & Universities ( 1 highly relevant, 0 other) & 0.07 & 0.25 \\
\hline PublicResearch & Other state institutions ( 1 highly relevant, 0 other) & 0.03 & 0.17 \\
\hline Universities, Publ. Res. & Universities or public research ( 1 highly relevant, 0 other) & 0.07 & 0.26 \\
\hline Exhibitions & Exhibitions, conferences ( 1 highly relevant, 0 other & 0.11 & 0.31 \\
\hline Journals & Scientific journals(1 highly relevant, 0 other) & 0.08 & 0.27 \\
\hline Associations & Associations (1 highly relevant, 0 other) & 0.04 & 0.20 \\
\hline Patents & Patent descriptions (1 highly relevant, 0 other) & 0.03 & 0.17 \\
\hline Standardization & Standardization committees ( 1 highly relevant, 0 other) & 0.04 & 0.19 \\
\hline \multicolumn{4}{|l|}{ Cooperation } \\
\hline Coop & R\&D cooperations 2006-2008 (1 yes, 0 no $)$ & 0.26 & 0.44 \\
\hline Self - Cooperation & $\begin{array}{l}\text { Realization of the eco-innovation: } 1 \text { within the firm or in cooperation } \\
\text { with other firms, } 0 \text { Predominantly by other firms }\end{array}$ & 0.71 & 0.45 \\
\hline \multicolumn{4}{|l|}{ Competition } \\
\hline Market entries & $\begin{array}{l}\text { Market position threatened by entry of new competitors ( } 1 \text { highly rele- } \\
\text { vant, } 0 \text { other) }\end{array}$ & 0.37 & 0.48 \\
\hline Foresee demand & $\begin{array}{l}\text { Development of demand is difficult to foresee ( } 1 \text { highly relevant, } 0 \\
\text { other) }\end{array}$ & 0.63 & 0.48 \\
\hline Competition intensity & High competition intensity by foreign firms ( 1 highly relevant, 0 other) & 0.36 & 0.48 \\
\hline \multicolumn{4}{|l|}{ Control variables } \\
\hline Size & Number of employees 2008 & 752 & 11083 \\
\hline Age & Age of the firm $(2008-$ year of foundation +0.5$)$ & 31.9 & 39.3 \\
\hline EastWest & 1 East Germany, 0 West Germany & 0.30 & 0.46 \\
\hline Innovator & Realised, not yet finished or interrupted innovations ( 1 yes, 0 no) & 0.62 & 0.49 \\
\hline Reduction EnvImpacts & $\begin{array}{l}\text { Reduction of environmental impacts as innovation goal ( } 1 \text { highly rele- } \\
\text { vant, } 0 \text { other) }\end{array}$ & 0.13 & 0.33 \\
\hline \multicolumn{4}{|l|}{ Sector dummies } \\
\hline Sec1 & Agriculture, mining, quarrying of stones & 0.01 & 0.11 \\
\hline $\operatorname{Sec} 2$ & Food products and beverages, tobacco & 0.05 & 0.21 \\
\hline Sec3 & Textiles, leather & 0.03 & 0.17 \\
\hline Sec4 & Processing of wood, paper, printing & 0.06 & 0.24 \\
\hline $\operatorname{Sec} 5$ & Chemical Industry & 0.04 & 0.20 \\
\hline Sec6 & Rubber and plastic products & 0.03 & 0.17 \\
\hline Sec7 & Glass, ceramics & 0.02 & 0.15 \\
\hline $\operatorname{Sec} 8$ & Basic metals and fabricated metals & 0.07 & 0.25 \\
\hline Sec9 & Machinery & 0.08 & 0.27 \\
\hline $\operatorname{Sec} 10$ & Electrical machinery and apparatus & 0.06 & 0.23 \\
\hline Sec11 & Precision and optical instruments & 0.05 & 0.22 \\
\hline Sec12 & Motor vehicles, other transport equipment & 0.03 & 0.18 \\
\hline Sec13 & Furniture & 0.02 & 0.15 \\
\hline
\end{tabular}




\begin{tabular}{|l|l|l|l|}
\hline Sec14 & Recycling, waste and waste water removal & 0.01 & 0.09 \\
$\operatorname{Sec} 15$ & Energy and water supply & 0.03 & 0.16 \\
$\operatorname{Sec} 16$ & Construction sector & 0.01 & 0.10 \\
$\operatorname{Sec} 17$ & Wholesale and retail trade & 0.04 & 0.19 \\
$\operatorname{Sec} 18$ & Transport and communication, & 0.06 & 0.24 \\
$\operatorname{Sec} 19$ & Banking sector, assurances, renting of cars and other products & 0.05 & 0.21 \\
$\operatorname{Sec} 20$ & Data processing, research and development, consulting & 0.15 & 0.36 \\
$\operatorname{Sec} 21$ & Other services & 0.12 & 0.32 \\
\hline
\end{tabular}

